\title{
Response of Sweet Sorghum Lines to Stalk Pathogens Fusarium thapsinum and Macrophomina phaseolina
}

Deanna L. Funnell-Harris and Patrick M. O’Neill, Grain, Forage and Bioenergy Research Unit (GFBRU), United States Department of Agriculture-Agricultural Research Service (USDA-ARS), and Department of Plant Pathology, and Scott E. Sattler and Melinda K. Yerka, GFBRU, USDA-ARS and Department of Agronomy and Horticulture, University of Nebraska, Lincoln 68583-0919

\begin{abstract}
Funnell-Harris, D. L., O’Neill, P. M., Sattler, S. E., Yerka, M. K. 2016. Response of sweet sorghum lines to stalk pathogens Fusarium thapsinum and Macrophomina phaseolina. Plant Dis. 100:896-903.

Sweet sorghum (Sorghum bicolor (L.) Moench) has potential for bioenergy. It is adapted to a variety of U.S. locations and the extracted juice can be directly fermented into ethanol. However, little research on fungal stalk rots, diseases that pose serious constraints for yield and quality of juice and biomass, has been reported. A greenhouse bioassay was designed to assess charcoal rot (Macrophomina phaseolina) and Fusarium stalk rot (Fusarium thapsinum) in plants at maturity, the developmental stage at which these diseases are manifested. Multiple plantings of a susceptible grain line, RTx430,

were used as a control for variation in flowering times among sweet sorghum lines. Lesion length measurements in inoculated peduncles were used to quantify disease severity. Sweet sorghum lines 'Rio' and 'M81E' exhibited resistance to $F$. thapsinum and $M$. phaseolina, respectively; and, in contrast, 'Colman' sorghum exhibited susceptibility to both pathogens. Lesion development over time in Colman was monitored. These results will enhance molecular and biochemical analyses of responses to pathogens, and breeding stalk-rot-resistant sweet sorghum lines.
\end{abstract}

Sorghum (Sorghum bicolor (L.) Moench) has a vast diversity of germplasm, which is primarily being used for food and feed. However, several bioenergy platforms - grain sorghum (starch-based bioethanol), forage sorghum (cellulose-based bioethanol and thermal conversion), and sweet sorghum (sugars) — are being used or are under development (Carpita and McCann 2008; Upadhyaya et al. 2009; Wu et al. 2010; Zegada-Lizarazu and Monti 2012). Similarly to its close relative, sugarcane (Saccharum spp.), the juice of sweet sorghum can be extracted and directly fermented into ethanol. Unlike sugarcane, sweet sorghum can be widely produced across the United States (Keeney and DeLuca 1992; Smith et al. 1987). Sweet sorghum was traditionally used for small-scale syrup or sugar production and, thus, was bred for stalk height (biomass), juice volume, sugar content, and juice extractability (Eggleston et al. 2013; Teetor et al. 2011; Wang et al. 2009). These traits also allowed sweet sorghums to be amenable for feeding ruminant animals plants or bagasse (biomass after juice extraction) (Smith and Frederiksen 2000; Whitfield et al. 2012).

Corresponding author: D. L. Funnell-Harris;

E-mail: Deanna.Funnell-Harris@ars.usda.gov

Mention of trade names or commercial products in this article is solely for the purpose of providing specific information and does not imply recommendation or endorsement by the United States Department of Agriculture (USDA). The USDA prohibits discrimination in all its programs and activities on the basis of race, color, national origin, age, disability, and where applicable, sex, marital status, familial status, parental status, religion, sexual orientation, genetic information, political beliefs, reprisal, or because all or part of an individual's income is derived from any public assistance program. (Not all prohibited bases apply to all programs.) Persons with disabilities who require alternative means for communication of program information (Braille, large print, audiotape, etc.) should contact USDA's TARGET Center at (202) 720-2600 (voice and TDD). To file a complaint of discrimination, write to USDA, Director, Office of Civil Rights, 1400 Independence Avenue, S.W., Washington, D.C. 20250-9410, or call (800) 795-3272 (voice) or (202) 720-6382 (TDD). USDA is an equal opportunity provider and employer.

Accepted for publication 4 January 2016.

http://dx.doi.org/10.1094/PDIS-09-15-1050-RE

This article is in the public domain and not copyrightable. It may be freely reprinted with customary crediting of the source. The American Phytopathological Society, 2016
Little research on fungal stalk, foliar, and root diseases of sweet sorghum has been reported (Dogget 1988; Zummo 1971, 1986; Zummo and Broadhead 1984). These diseases pose a serious constraint for yield and quality of sweet sorghum juice and bagasse (FunnellHarris et al. 2014; Rajewski and Francis 1991; Tesso and Ejeta 2011). In particular, stalk diseases can reduce biomass and are associated with lodging, which reduces the harvestable yield (Bean et al. 2013; Funnell-Harris et al. 2014; Miron et al. 2005; Rajewski and Francis 1991; Tesso et al. 2005).

Control of sorghum stalk diseases has been challenging, due to the diversity of fungi with relatively broad host ranges that are responsible for these diseases (Jardine and Leslie 1992; Saleh et al. 2010; Su et al. 2001; Tesso et al. 2010). Plant breeding has focused on identifications of quantitative trait loci and traits associated with increased resistance or tolerance. These traits include drought tolerance and postflowering nonsenescence, a trait called "stay-green" (Borrell et al. 2014; Tenkouano et al. 1993; Tesso et al. 2005). Sweet sorghum breeding has focused on stalk traits such as biomass, juice, and sugar content that increase usability for bioenergy (Audilakshmi et al. 2010; Lv et al. 2013; Shiringani et al. 2010). There are no known publications on breeding sweet sorghum for increased resistance or tolerance to stalk pathogens.

The present research focused on two major sorghum stalk diseases, Fusarium stalk rot and charcoal rot (Bramel-Cox and Claflin 1989; Funnell-Harris et al. 2014; Jardine and Leslie 1992; Odvody and Dunkle 1979; Tesso and Ejeta 2011; Tesso et al. 2010). The primary Fusarium spp. infecting sorghum stalks include Fusarium andiyazi Marasas, Rheeder, Lampr., K. A. Zeller \& J. F. Leslie; F. proliferatum (Matsush.) Nirenberg ex Gerlach \& Nirenberg; F. thapsinum (authoritative name, Gibberella thapsina Klittich, J. F. Leslie, P. E. Nelson \& Marasas); and F. verticillioides (authoritative name: G. fujikuroi (Sawada) Wollenw.) (Funnell-Harris and Pedersen 2008; Funnell-Harris et al. 2014; Tesso et al. 2010). These species cause infections that can result in deterioration of stalk pith cells, associated with senescence during grain development (Reed and Partridge 1983). Macrophomina phaseolina (Tassi) Goid. causes infections that result in similar deterioration of the stalk but also form dark sclerotia along the degraded vascular bundles of the colonized stalk and roots (Rao et al. 1980; Russin et al. 1995); therefore, it was given the name "charcoal rot."

Based on previous published research (Davila-Gomez et al. 2011; Pfeiffer et al. 2010) (http://www.ars-grin.gov/npgs/) of brix (indicating sugar level), six lines were chosen as breeding materials for further 
improvement of bioenergy sweet sorghum. Five lines ('Theis,' 'Dale,' 'Wray,' 'M81E', and 'Colman') were previously reported to be resistant to lodging whereas the sixth line ('Rio') has no known reports (https:// npgsweb.ars-grin.gov/gringlobal/descriptordetail.aspx?id=69023), and there are no known reports of resistance or susceptibility to stalk rot pathogens for any of these six lines. Therefore, it was necessary to assess responses of these lines to stalk rot pathogens under controlled conditions, and a greenhouse assay was developed to accomplish this. There have been no previously published reports of sweet sorghum pathology assays under controlled conditions. To account for large variation in flowering time among the sweet sorghum lines, several successive plantings of a grain sorghum line susceptible to the pathogens were used for comparison (Funnell and Pedersen 2006a; Funnell-Harris and Pedersen 2008; Funnell-Harris et al. 2014) (unpublished). In this way, the following hypothesis was tested: Among sweet sorghum lines, differential responses to stalk pathogens can be identified.

\section{Materials and Methods}

Plant lines. Sorghum lines Colman, Dale, M81E, Rio, Theis, Wray, RTx430, SC599, and SC1154 were utilized in this study (Table 1). SC599 and SC1154 were obtained from the National Plant Germplasm System, (PI534163 and PI59572, respectively), and were previously reported to be resistant to Fusarium spp. and M. phaseolina (Tesso et al. 2005, 2010), while RTx430 has previously demonstrated susceptibility to these pathogens (Funnell and Pedersen 2006a; Funnell-Harris and Pedersen 2008; Funnell-Harris et al. 2014) (unpublished). RTx430, SC599, and SC1154 are all "combine height." Grain used in assays was produced in greenhouses at the University of Nebraska, Lincoln, Plant Growth Facilities.

Fungi and media. G. thapsina isolate H03S-11-9 (Funnell-Harris et al. 2010) and M. phaseolina isolate MP01-001 (a kind gift from G. Odvody, Texas A \& M Agrilife Research and Extension Center, Corpus Christi) were maintained on one-half strength potato dextrose agar (PDA), made using potato dextrose broth (PDB; Becton, Dickinson and Co., Sparks, MD) amended with ampicillin (SigmaAldrich, St. Louis) at $100 \mu \mathrm{g} \mathrm{ml}^{-1}$. G. thapsina is referred to in the text by its more familiar name, $F$. thapsinum. To prepare inoculum, five agar disks ( $5 \mathrm{~mm}$ in diameter) from the growing edge of 4-dayold cultures on PDA were inoculated into $25 \mathrm{ml}$ of sterile PDB in $150-\mathrm{ml}$ beakers with sterile toothpicks, previously treated to remove toxins and other inhibitors to fungal growth (Jardine and Leslie 1992). The broth-and-toothpick cultures were incubated at room temperature $\left(22\right.$ to $\left.23^{\circ} \mathrm{C}\right)$ for 10 days before use.

Peduncle inoculations. Two repetitions were planted beginning in early summer (repetition [rep.] 1) and midsummer (rep. 2) 2013 (Table 1). Based on previous field or greenhouse observations, the sweet sorghum lines and resistant checks were planted at different times to compensate for differences in flowering times between lines and to attempt to synchronize flowering times. RTx430 was also planted in four (rep. 1) or five (rep. 2) plantings per repetition (A to I) for use as a susceptible check for greenhouse conditions at various times throughout the season.

Seed were sown into pots $(25.4 \mathrm{~cm}$ in diameter) containing pasteurized soil mix (one part sand, one part coarse vermiculite, one part top soil, and two parts shredded peat moss). Seedlings were culled to one plant per pot. Inoculations (Table 1) were conducted on plants at anthesis (defined as one-half the anthers exerted). Peduncles were probed with a surface-disinfested awl to form a shallow hole ( $2 \mathrm{~mm}$ in diameter); then, a fungal-inoculated toothpick was inserted into the hole. Eighteen days following inoculation, the peduncle was split longitudinally and the length of the red to purple discoloration (the lesion) was measured. Control inoculations with sterile broth were used to account for pigmentation commonly resulting from wounding in sorghum.

The experimental design was randomized incomplete block with at least two lines (RTx430 and at least one sweet sorghum or resistant check) and three treatments ( $F$. thapsinum, M. phaseolina, and broth), with six replications, blocked by time of inoculation and location. The data were analyzed using the PROC MIXED procedure of SAS/STAT software (data analysis for this article was generated using SAS/STAT software; SAS and all other SAS Institute Inc. product or service names are registered trademarks of SAS Institute Inc. in the United States and other countries; SAS 2002-2008). The results from RTx430 inoculations were used to make comparisons across inoculation dates and between treatments. For comparisons of results between treatments on the same inoculation date, the data were treated as a randomized complete block (RCB) design, with six replicate blocks and two repetitions of the entire experiment. Data sets were analyzed for Levene's homogeneity of variance (HoV) and appropriate adjustments were incorporated using the REPEATED/GROUP option of PROC

Table 1. Field observations for plant heights and days to anthesis; planting and inoculation (at anthesis) dates for two repetitions of peduncle inoculation assays ${ }^{\mathrm{w}}$

\begin{tabular}{|c|c|c|c|c|c|c|}
\hline \multirow[b]{2}{*}{ Lines } & \multicolumn{2}{|c|}{ Field observations $^{x}$} & \multicolumn{2}{|c|}{ Repetition 1} & \multicolumn{2}{|c|}{ Repetition 2} \\
\hline & Days to anthesis & Height $(\mathrm{cm})$ & Planting date & Inoculation date & Planting date & Inoculation date \\
\hline \multicolumn{7}{|c|}{ Sweet sorghum } \\
\hline Colman & 84.6 & 300.0 & 14 August 2013 & 11 October 2013 & 29 October 2013 & 22 January 2014 \\
\hline Dale & 94.8 & 331.7 & 26 June 2013 & 5 September 2013 & 18 September 2013 & 16 December 2013 \\
\hline M81E & 95.2 & 343.3 & 26 June 2013 & 5 September 2013 & 21 August 2013 & 25 November 2013 \\
\hline Rio & 91.6 & 340.0 & 19 August 2013 & 26 September 2013 & 18 September 2013 & 25 November 2013 \\
\hline Theis & 99.4 & 343.3 & 26 June 2013 & 26 September 2013 & 21 August 2013 & $\begin{array}{l}25 \text { November } 2013(16) \\
16 \text { December } 2013(2)\end{array}$ \\
\hline Wray & 91.0 & 325.0 & 21 August 2013 & 21 October 2013 & 29 October 2013 & 5 March 2014 \\
\hline \multicolumn{7}{|c|}{ Resistant checks } \\
\hline SC599 & ND & $122^{y}$ & 8 August 2013 & 21 October 2013 & 1 November 2013 & 10 February 2014 \\
\hline SC1154 & ND & $\mathrm{ND}^{\mathrm{z}}$ & 8 August 2013 & 11 October 2013 & 1 November 2013 & $\begin{array}{l}10 \text { February } 2014(16), \\
2 \text { March } 2014 \text { (2) }\end{array}$ \\
\hline \multicolumn{7}{|c|}{ Susceptible check } \\
\hline \multirow[t]{5}{*}{$\mathrm{RTx} 430$} & 81.6 & 123.3 & 10 July 2013 & 5 September 2013 (A) & 10 September 2013 (E) & 25 November 2013 \\
\hline & $\ldots$ & $\ldots$ & 24 July 2013 & 26 September 2013 (B) & 24 September 2013 (F) & 16 December 2013 \\
\hline & $\ldots$ & $\ldots$ & 7 August 2013 & 11 October $2013(\mathrm{C})$ & 9 October $2013(\mathrm{G})$ & 22 January 2014 \\
\hline & $\ldots$ & $\ldots$ & 21 August 2013 & 21 October 2013 (D) & 29 October $2013(\mathrm{H})$ & 10 February 2014 \\
\hline & $\ldots$ & $\ldots$ & $\ldots$ & $\ldots$ & 20 November 2013 (I) & 5 March 2014 \\
\hline
\end{tabular}

\footnotetext{
w ND denotes "not determined." Means were calculated based on three plots. Means are shown; SE are 1.8

y Mean height of SC599 published in National Plant Germplasm System (NPGS) (http://www.ars-grin.gov/npgs/).

z In NPGS, SC1154 is listed as being "combine height," similar to other grain sorghums.
}

x Field observations were made during summer 2014. Average plant height was estimated at maturity. Measurements on each of five plots were rounded to the nearest $5 \mathrm{~cm}$. Means are shown; standard errors (SE) are 8.3. Days-to-anthesis was determined when the anthers from half the plants in a plot were exerted. 
MIXED (SAS 2002-2008). Least squares means (LSM) and standard errors (SE) are reported.

Peduncle lesion development. Experiments were conducted to observe the initiation and development of lesions in peduncles of Colman sweet sorghum. Two assays were planted in early summer (assay 1) and midsummer (assay 2) 2014. In assay 1, 72 Colman plants were grown and peduncles were inoculated as described above, with toothpicks incubated with one of the three treatments: either $F$. thapsinum, M. phaseolina, or broth. After inoculation (time point 0 days), four plants of each treatment were assessed for lesion length on days $0,1,3,7,14$, and 18 postinoculation. RTx430 also was grown but the plants did not reach anthesis at the same time as Colman; therefore, inoculations were not performed. The experimental design for assay 1 was RCB with one line, three treatments, and six time points per treatment in four replications blocked by location. Results of assay 1 were used to adjust time points for assay 2 . For assay 2, 72 plants each of Colman and RTx430 were grown and inoculated; four plants of each line and treatment were assessed for resulting lesion length on days $0,3,6,9,13$, and 16 postinoculation. The experimental design was RCB with two lines, three treatments, and six time points per treatment and line in four replications, blocked by location in the greenhouse.

For each time point assay, regression analyses were performed in order to compare between treatments (time point assays 1 and 2) and between lines for a given treatment (time point assay 2). Data were analyzed using the PROC MIXED procedure of SAS/STAT software (SAS 2002-2008). Each line for each assay was analyzed separately. Because lesion measurement is destructive, measurements at each time point were performed on a different set of plants. The KENWARD-ROGER option was specified for estimating degrees of freedom. Slope was estimated using the SOLUTION option. Confidence intervals for the slopes were set at $P=0.05$. Comparisons between treatments in a given line (assays 1 and 2) or between lines with the same treatment (assay 2) were made using single degree-of-freedom contrasts. Slope estimates and SE are reported.

For comparison of lesion length at each time point for a given treatment and plant line, the PROC MIXED procedure of SAS/STAT software (SAS 2002-2008) was used. The KENWARD-ROGER option was specified for estimating degrees of freedom. For analysis of

Table 2. Analyses of variance of fixed effects (line, treatment [Trt], and inoculation date) and interactions for inoculations of sweet sorghum lines and resistant checks with Fusarium thapsinum, Macrophomina phaseolina, and control as compared with susceptible check RTx430z

\begin{tabular}{|c|c|c|c|c|c|c|c|c|}
\hline \multirow[b]{2}{*}{ Line } & \multirow[b]{2}{*}{ Statistic } & \multicolumn{7}{|c|}{ Summary statistics from type 3 tests of fixed effects } \\
\hline & & Line (L) & Trt $(\mathbf{T})$ & Date (D) & $\mathbf{L} \times \mathbf{T}$ & $\mathbf{L} \times \mathbf{D}$ & $\mathbf{T} \times \mathbf{D}$ & $\mathbf{L} \times \mathbf{T} \times \mathbf{D}$ \\
\hline \multicolumn{9}{|c|}{ Susceptible check } \\
\hline \multirow[t]{2}{*}{ RTx430 } & $F$ value & na & 27.30 & 1.52 & na & na & 1.80 & na \\
\hline & $P$ value & na & $<0.01$ & 0.16 & na & na & 0.04 & na \\
\hline \multicolumn{9}{|c|}{ Sweet sorghum } \\
\hline \multirow[t]{2}{*}{ Colman } & $F$ value & 18.08 & 14.59 & 6.40 & 6.01 & 5.98 & 10.08 & 3.23 \\
\hline & $P$ value & $<0.01$ & $<0.01$ & 0.02 & 0.01 & 0.02 & $<0.01$ & 0.06 \\
\hline \multirow[t]{2}{*}{ Dale } & $F$ value & 4.23 & 34.27 & 37.92 & 0.15 & 1.08 & 3.17 & 1.59 \\
\hline & $P$ value & 0.05 & $<0.01$ & $<0.01$ & 0.87 & 0.31 & 0.06 & 0.22 \\
\hline \multirow[t]{2}{*}{ M81E } & $F$ value & 0.00 & 9.48 & 1.81 & 0.23 & 0.27 & 4.87 & 0.50 \\
\hline & $P$ value & 1.00 & $<0.01$ & 0.18 & 0.80 & 0.61 & 0.01 & 0.61 \\
\hline \multirow[t]{2}{*}{ Rio } & $F$ value & 1.39 & 20.07 & 0.51 & 1.86 & 4.56 & 1.64 & 1.39 \\
\hline & $P$ value & 0.24 & $<0.01$ & 0.48 & 0.17 & 0.04 & 0.20 & 0.26 \\
\hline \multirow[t]{2}{*}{ Theis } & $F$ value & 0.43 & 8.91 & 0.88 & 0.57 & 0.00 & 3.11 & 1.84 \\
\hline & $P$ value & 0.51 & $<0.01$ & 0.35 & 0.57 & 0.98 & 0.05 & 0.17 \\
\hline \multirow[t]{2}{*}{ Wray } & $F$ value & 12.45 & 72.81 & 0.21 & 12.22 & 0.28 & 0.41 & 3.87 \\
\hline & $P$ value & $<0.01$ & $<0.01$ & 0.65 & $<0.01$ & 0.60 & 0.66 & 0.03 \\
\hline \multicolumn{9}{|c|}{ Resistant checks } \\
\hline \multirow[t]{2}{*}{ SC599 } & $F$ value & 9.64 & 49.23 & 0.79 & 1.53 & 0.16 & 3.97 & 5.61 \\
\hline & $P$ value & $<0.01$ & $<0.01$ & 0.38 & 0.22 & 0.69 & 0.02 & 0.01 \\
\hline \multirow[t]{2}{*}{ SC1154 } & $F$ value & 54.31 & 12.06 & 0.74 & 0.24 & 0.01 & 1.25 & 0.99 \\
\hline & $P$ value & $<0.01$ & $<0.01$ & 0.39 & 0.79 & 0.91 & 0.29 & 0.38 \\
\hline
\end{tabular}

${ }^{\mathrm{z}}$ Peduncles were inoculated at anthesis with toothpicks infested with one of the two fungi or broth (control). Due to variabilities in flowering, the susceptible check RTx430 was included at each inoculation date. The response variable was lesion length $(\mathrm{mm})$, measured 18 days after inoculation; na indicates not applicable.

Table 3. Response of susceptible grain sorghum line RTx430 to peduncle inoculations with the stalk pathogens Fusarium thapsinum and Macrophomina phaseolina or with broth control at nine times over 6 months under greenhouse conditions ${ }^{\mathrm{z}}$

\begin{tabular}{lccc}
\hline & \multicolumn{3}{c}{ Treatments } \\
\cline { 2 - 4 } Inoculation dates & $\boldsymbol{F}$ thapsinum & M. phaseolina & Broth control \\
\hline 5 September 2013 (A) & $104.3 \mathrm{a}, 1 \pm 13.5$ & $64.5 \mathrm{ab}, \mathrm{m} \pm 13.5$ & $10.2 \mathrm{a}, \mathrm{n} \pm 13.5$ \\
26 September 2013 (B) & $108.2 \mathrm{a}, 1 \pm 13.5$ & $30.0 \mathrm{~b}, \mathrm{~m} \pm 13.5$ & $17.7 \mathrm{a}, \mathrm{m} \pm 13.5$ \\
11 October 2013 (C) & $63.8 \mathrm{~b}, 1 \pm 13.5$ & $35.8 \mathrm{ab}, \mathrm{lm} \pm 13.5$ & $18.7 \mathrm{a}, \mathrm{m} \pm 13.5$ \\
21 October 2013 (D) & $58.7 \mathrm{~b}, 1 \pm 13.5$ & $39.3 \mathrm{ab}, \mathrm{lm} \pm 13.5$ & $4.7 \mathrm{a}, \mathrm{m} \pm 13.5$ \\
25 November 2013 (E) & $49.6 \mathrm{~b}, 1 \pm 14.8$ & $71.2 \mathrm{a}, 1 \pm 14.8$ & $7.3 \mathrm{a}, \mathrm{m} \pm 13.5$ \\
16 December 2013 (F) & $42.6 \mathrm{~b}, 1 \pm 14.8$ & $29.2 \mathrm{~b}, 1 \pm 13.5$ & $12.8 \mathrm{a}, 1 \pm 14.8$ \\
2 January 2014 (G) & $33.0 \mathrm{~b}, \mathrm{~lm} \pm 16.6$ & $61.7 \mathrm{ab}, 1 \pm 13.5$ & $20.8 \mathrm{a}, \mathrm{m} \pm 13.5$ \\
10 February 2014 (H) & $58.3 \mathrm{~b}, 1 \pm 11.7$ & $31.0 \mathrm{~b}, \mathrm{~lm} \pm 13.5$ & $8.0 \mathrm{a}, \mathrm{m} \pm 13.5$ \\
5 March 2014 (I) & $43.4 \mathrm{~b}, 1 \pm 14.8$ & $44.0 \mathrm{ab}, 1 \pm 14.8$ & $25.6 \mathrm{a}, 1 \pm 14.8$ \\
\hline
\end{tabular}

${ }^{\mathrm{z}}$ Peduncles of RTx430 plants were wound inoculated at anthesis with toothpicks incubated in a broth culture of $F$. thapsinum, M. phaseolina, or sterile broth (control). Eighteen days later, peduncles were split longitudinally and lesion lengths were measured. The first letters (a, ab, or b) are for comparisons of mean lesion lengths from the same treatment across inoculation dates (column). The second letters (l, lm, m, or $\mathrm{n}$ ) are for comparisons of different treatments at the same inoculation date (row). Comparisons with differing letters are significantly different at $P \leq 0.05$. 
time course assay 1, an HoV statement was added to adjust for variance between treatments. LSM and SE are reported.

\section{Results}

Response of the susceptible check (RTx430) to $F$. thapsinum and $M$. phaseolina inoculated at different times in the greenhouse. The susceptible grain sorghum line RTx 430 was planted nine different times under greenhouse conditions (Table 1). All plants were inoculated at anthesis with identically prepared fresh inoculum; there was no significant effect due to inoculation date $(P=0.16)$ (Table 2). Across all inoculation dates, mean lesion lengths (in millimeters) were significant for treatment: inoculations with $F$. thapsinum, $M$. phaseolina, and broth control were $62.4 \pm 4.8,45.2 \pm 4.6$, and $14.0 \pm 4.6 \mathrm{~mm}$, respectively $(P<0.01)$. The interactions of inoculation date with treatment were significant $(P=0.04$; Table 2$)$. This interaction may be due to inoculations with $F$. thapsinum, which resulted in significantly greater mean lesion lengths in late summer or early fall than inoculations occurring during fall or winter (Table 3; comparisons in columns). Inoculation date had a less pronounced effect on mean lesion lengths of $M$. phaseolina-inoculated plants, and did not significantly affect the broth control when comparing responses at different dates. Mean lesion lengths resulting from pathogen inoculations were not always significantly greater than the lengths from broth inoculation due to pigmentation resulting from wounding response of the plant (Table 3; comparisons across rows).

Responses of sweet sorghum lines to $F$. thapsinum and M. phaseolina. Peduncle inoculations were conducted because these assays yield consistent results with relatively few replications; therefore, these assays are valuable for screening several plant genotypes and inoculum treatments for responses to stalk pathogens (FunnellHarris and Pedersen 2008; Funnell-Harris et al. 2014). Sorghum plants were inoculated at anthesis with either $F$. thapsinum or M. phaseolina and compared with the susceptible check RTx430, inoculated at the same time. The key test statistics and significance levels for main

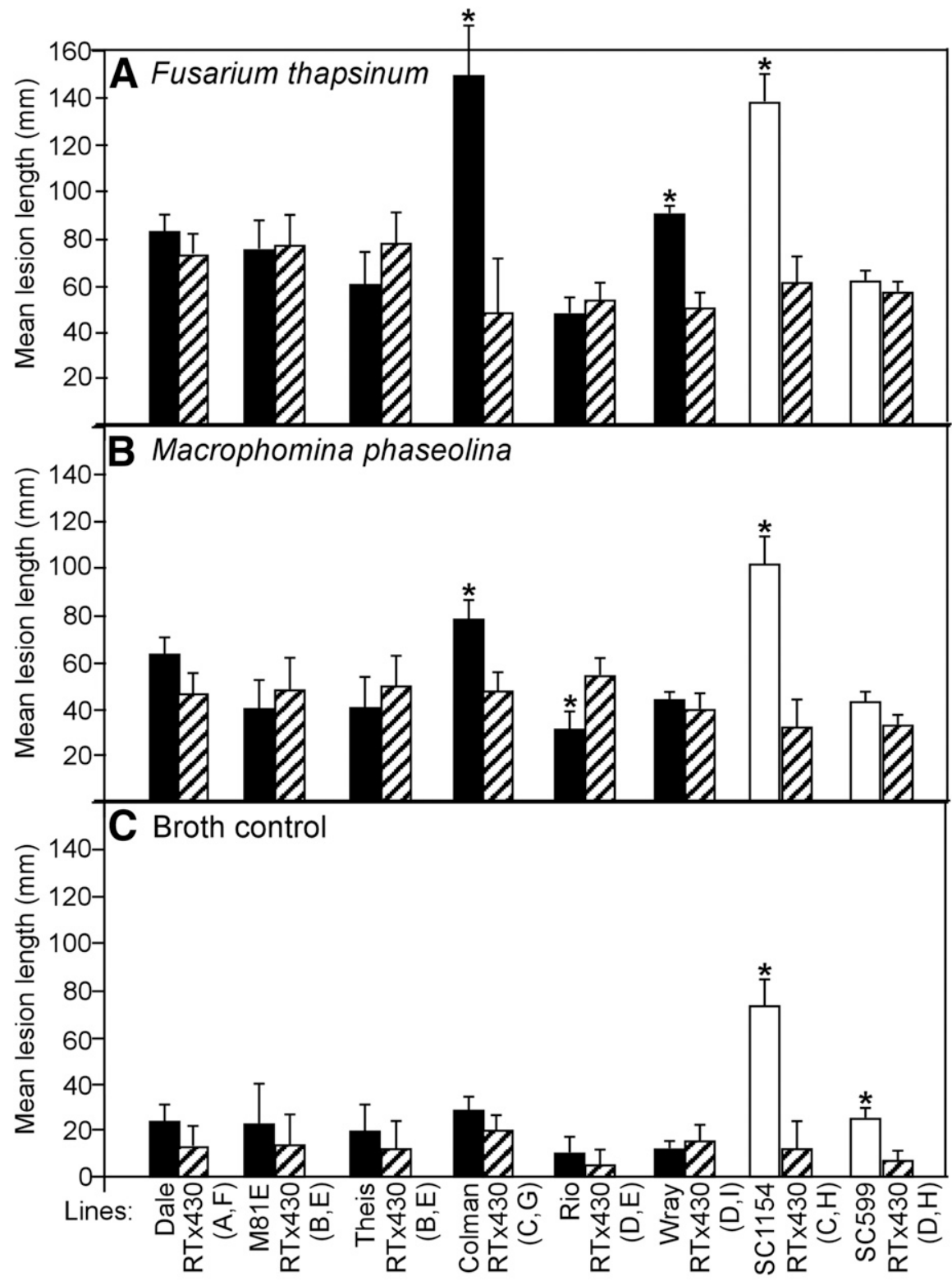

Sweet sorghum line $\quad$ DSusceptible line $\square$ Resistant line

Fig. 1. Mean lesion lengths on sweet sorghum (solid black bars) and resistant checks (solid white bars) as compared with the susceptible check (diagonal hatch marks) following wound inoculation with A, Fusarium thapsinum; B, Macrophomina phaseolina; and C, broth control. Peduncles of plants were inoculated with one of the fungi or with sterile broth. Eighteen days following inoculation, the peduncles were split longitudinally and the lengths of the resulting lesions were measured. Each sorghum line was inoculated at the same time as susceptible line RTx430. On the horizontal axis, letters following RTx430 indicate the replications within each repetition; inoculations with the same letter were inoculated at the same time. Mean lesion lengths and positive standard errors are shown. An asterisk indicates that the mean lesion length is significantly different $(P \leq 0.05)$ than that resulting on RTx430. 
effects and their interactions are shown in Table 2 and mean lesion lengths are illustrated in Figure 1. Results from sweet sorghum lines indicate that Colman is more susceptible to both pathogens and Wray is more susceptible to $F$. thapsinum than RTx430 ( $P \leq 0.01)$, while Rio exhibits more resistance to $M$. phaseolina than RTx430 in this assay $(P=0.05)$ (Fig. 1A and B). In addition, SC1154 (resistant check) appears to be highly susceptible to both pathogens $(P<0.01)$ following greenhouse peduncle wound inoculations. Also, the wound responses of the resistant checks SC1154 and SC599 were significantly greater $(P<0.01)$ than those of RTx 430 based on the broth control inoculation (Fig. 1C). Differences in response to wounding and the broth control in different sorghum lines have been previously observed (Funnell and Pedersen 2006a). To better discern the response due to pathogen inoculation as opposed to wound response (broth control), differences between LSM of lesion lengths due to inoculation with each pathogen and length following inoculation with the broth control were determined (Table 4). This analysis confirmed that Colman was susceptible to both pathogens in this assay. Following this analysis, it was clear that mean lesion length resulting on Rio was statistically similar to that on resistant check SC599 (Fig. 1A; Table 4). Difference of the mean lesion length resulting on M81E following inoculation with $M$. phaseolina was not significantly different than the broth control (Table 4). These analyses indicated that Rio may have resistance to $F$. thapsinum and M81E may have resistance to M. phaseolina, while Colman is highly susceptible to both pathogens.

Lesion development within the susceptible sweet sorghum line, Colman. Colman exhibited susceptibility to both pathogens, especially when compared with responses of resistant check SC599 to F. thapsinum and M. phaseolina (Fig. 1; Table 4). Therefore, documenting the lesion development within peduncles of the highly susceptible Colman was undertaken to understand disease progression. The purpose of these assays was to determine the number of days after inoculation in which initiation of a visible lesion and significant expansion of the lesion were observed. Colman (assays 1 and 2) and RTx430 (assay 2) plants were wound inoculated at anthesis with toothpicks incubated in $F$. thapsinum or $M$. phaseolina cultures, or in sterile broth, as previously described. Plants were harvested and lesion lengths measured over a time course. Regression analyses demonstrated that lesions forming in pathogen-inoculated peduncles were expanding at a greater rate (in millimeters per day) than the wound responses which resulted from sterile broth inoculation (Table 5). In the case of M. phaseolina inoculations, lesion expansion was significantly faster $(P=0.03)$ within Colman versus RTx430 peduncles.

Table 4. Difference in least squares means (LSM) of lesion lengths relative to the broth control for sorghum lines inoculated with Fusarium thapsinum or Macrophomina phaseolina ${ }^{\mathrm{z}}$

\begin{tabular}{|c|c|c|c|c|}
\hline \multirow[b]{2}{*}{ Line } & \multicolumn{2}{|c|}{ F. thapsinum } & \multicolumn{2}{|c|}{ M. phaseolina } \\
\hline & $\begin{array}{c}\text { Diff (mm) } \\
\text { LSM }_{\text {Ft-broth }}\end{array}$ & $\operatorname{Pr}>t$ & $\begin{array}{c}\text { Diff (mm) } \\
\text { LSM Mp-broth }^{\text {Methe }}\end{array}$ & $\operatorname{Pr}>t$ \\
\hline \multicolumn{5}{|c|}{ Sweet sorghum line } \\
\hline Colman & 119.4 & $<0.01$ & 48.9 & 0.07 \\
\hline Dale & 61.6 & $<0.01$ & 42.2 & $<0.01$ \\
\hline M81E & 54.1 & 0.01 & 19.6 & 0.35 \\
\hline Rio & 36.8 & $<0.01$ & 20.9 & 0.05 \\
\hline Theis & 39.6 & 0.03 & 21.1 & 0.24 \\
\hline Wray & 80.7 & $<0.01$ & 33.7 & $<0.01$ \\
\hline \multicolumn{5}{|c|}{ Resistant checks } \\
\hline SC1154 & 63.5 & $<0.01$ & 28.3 & 0.09 \\
\hline SC599 & 36.7 & $<0.01$ & 18.9 & $<0.01$ \\
\hline \multicolumn{5}{|c|}{ Susceptible check } \\
\hline RTx430 & 48.5 & $<0.01$ & 31.2 & $<0.01$ \\
\hline
\end{tabular}

In time course assay 1, visible lesions developed between day 1 and day 3: no visible lesions were apparent at day 1 but lesions were apparent by day 3 on many peduncles in both fungal inoculation and control (Fig. 2A). Lesions appeared to expand rapidly from day 7 to 14 in Colman peduncles, and mean lesion lengths were significantly greater than those of earlier time points for both pathogens $(P<0.01)$ at day 14. For time course 2, adjustments were made based on results of time course 1: an additional time point was added between 3 and 14 days and the susceptible check RTx 430 was included. By day 3 , the presence of lesions was visible in both lines with both fungal inoculations in this assay (Fig. 2B). Lesions expanded from days 9 to 13 for both fungal treatments in Colman; lesion lengths were significantly greater at day 13 than the earliest time point $(P \leq 0.01)$. Lesion expansion appeared to occur earlier, from days 6 to 9, in RTx430 peduncles compared with Colman peduncles; hence, mean lesion lengths were significantly greater at day 9 than day $0(P \leq 0.01)$ in RTx 430 . The lesions rapidly expanded between days 13 and 16 following inoculation with $F$. thapsinum; mean lesion length was significantly greater than at all other time points $(P<0.01)$ at day 16 in RTx430 (Fig. 2B). In this assay, there were no significant differences in mean lesion lengths of broth control inoculations between lines $(P=0.12$; Table 4) or different time points within a line ( $P \geq 0.21$; Fig. $2 \mathrm{~B})$.

\section{Discussion}

This study determined that sweet sorghum lines differentially respond to the stalk pathogens $F$. thapsinum and M. phaseolina that cause Fusarium stalk rot and charcoal rot, respectively. Rio exhibited greater resistance or tolerance to $F$. thapsinum, similar to that of the resistant check, SC599. M81E had lesion lengths following inoculation with M. phaseolina similar to those observed with the broth control (wound response). Colman was highly susceptible to both pathogens (Table 4; Fig. 1). Thus, resistance to both stalk pathogens exists in sweet sorghum lines; therefore, it may not be necessary to use other sorghum germplasm to develop improved sweet sorghum lines with resistance to both pathogens ( $\mathrm{Lv}$ et al. 2013; Pfeiffer et al. 2010; Shiringani et al. 2010).

Although controlled greenhouse assays with sweet sorghum have been reported (Luo et al. 2012; Nimir et al. 2015), there have been no reports, to our knowledge, of pathology assays conducted on mature plants. Because stalk rots manifest themselves at anthesis (Tenkouano et al. 1993; Tesso et al. 2005, 2010), it was necessary to grow plants to near full maturity. Both photoperiod and temperature affect flowering in sorghum (Major et al. 1990; Prasad et al. 2008; Yanase et al. 2008).

Table 5. Rate of lesion expansion from regression analyses of lesion lengths following inoculation with the stalk pathogens Fusarium thapsinum and Macrophomina phaseolina and the broth control

\begin{tabular}{|c|c|c|c|}
\hline \multirow[b]{3}{*}{ Treatment } & \multicolumn{3}{|c|}{ Lesion expansion $\left(\mathrm{mm} \mathrm{day}^{-1}\right)^{\mathrm{x}}$} \\
\hline & \multirow{2}{*}{$\frac{\text { Assay }^{\mathbf{y}}}{\text { Colman }}$} & \multicolumn{2}{|c|}{ Assay $2^{z}$} \\
\hline & & Colman & RTx430 \\
\hline F. thapsinum & $6.90 \mathrm{a} \pm 0.91$ & $5.40 \mathrm{a} \pm 0.69$ & $6.99 \mathrm{a} \pm 1.87$ \\
\hline M. phaseolina & $3.41 \mathrm{~b} \pm 0.86$ & $4.09 \mathrm{a}^{*} \pm 0.41$ & $2.31 \mathrm{~b} \pm 0.69$ \\
\hline Control & $1.29 \mathrm{c} \pm 0.45$ & $1.38 \mathrm{~b} \pm 0.33$ & $0.77 \mathrm{c} \pm 0.19$ \\
\hline
\end{tabular}

${ }^{\mathrm{x}}$ Letters indicate comparisons of different treatments in a given line and assay (vertical columns). Mean slopes with differing letters are significantly different at $P \leq 0.05$. The asterisk indicates that the mean slope of lesion expansion on Colman following inoculation with M. phaseolina is significantly greater than that on RTx430.

y Peduncles of Colman plants at anthesis were wounded with surfacedisinfested awls and inoculated with a toothpick incubated in a broth culture of each fungus or in broth alone. On days $0,1,3,7,14$, and 18, lesion lengths of four randomly chosen plants were measured. On day 1 , no lesion was apparent; therefore, lesion length was assumed to be the awl diameter $(2 \mathrm{~mm})$ Mean lesion length at day 0 was also assumed to be $2 \mathrm{~mm}$. Slope estimates and standard errors (SE) are shown.

${ }^{\mathrm{z}}$ Peduncles of Colman and RTx430 plants at anthesis were inoculated as described for assay 1 . On days $0,3,6,9,13$, and 16 , lesion lengths of four randomly chosen plants were measured. Mean lesion length at day 0 was assumed to be $2 \mathrm{~mm}$. Slope estimates and SE from comparisons within a line are shown. 
Therefore, multiple plantings of susceptible grain sorghum line RTx430 were included in the current study, as a benchmark for the greenhouse conditions at the time the sweet lines were inoculated (Boedo et al. 2012; Buttner et al. 2004; Padley et al. 2008). However, lesion lengths resulting from inoculation with $F$. thapsinum were affected by greenhouse conditions, which had been previously observed (Funnell-Harris and Pedersen 2008; Funnell-Harris et al. 2010, 2014; Paul and Munkvold 2005; Pedersen and Morrall 1994;
Shpialter et al. 2009). Conducting repetitions of the experiment at different times of the year addressed the potential effects of seasonality on stalk rot development and associated plant responses (Dorrance and Inglis 1997; English and Beuselinck 2000). Additionally, two lines (SC599 and SC1154) previously reported to be resistant to both $F$. thapsinum and M. phaseolina in field studies (Tesso et al. 2005, 2010) were included. During the present greenhouse study, SC599 exhibited responses consistent with those previously reported but SC1154 appeared to
A Time point assay 1
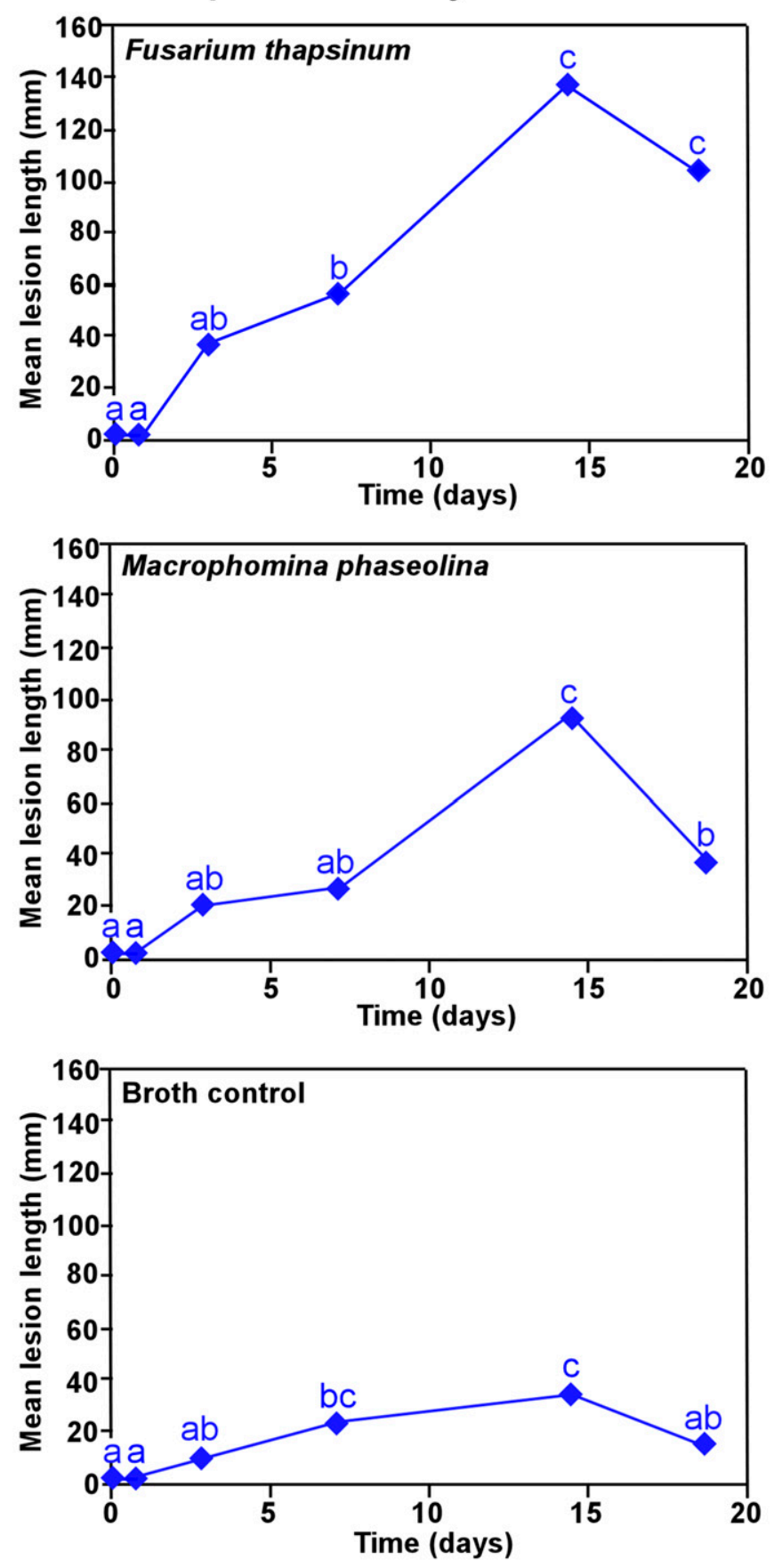

Sorghum line:
B Time point assay 2
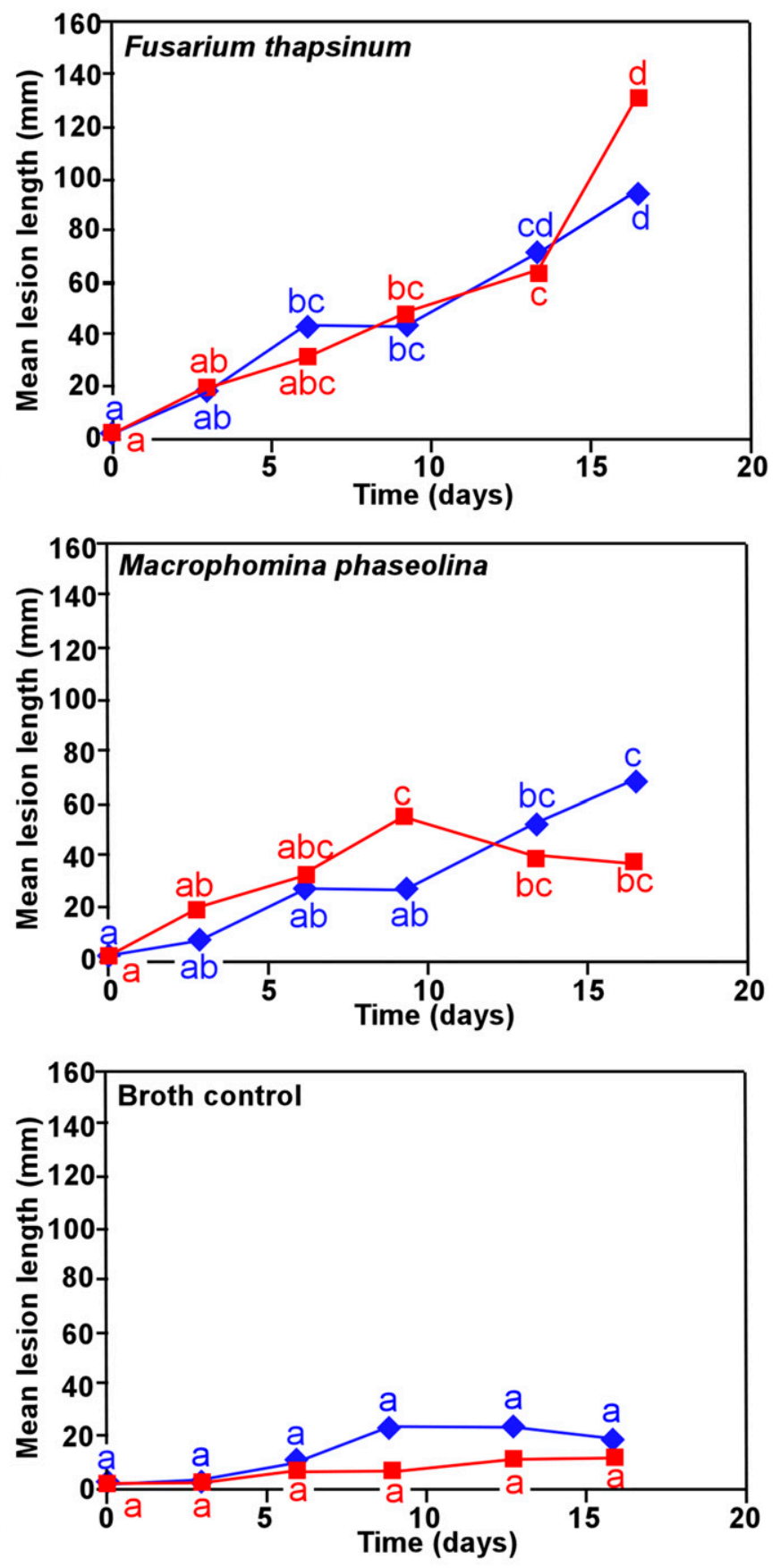

Fig. 2. Lesion development after peduncle inoculations in $\mathbf{A}$ and $\mathbf{B}$, sweet sorghum Colman and $\mathbf{B}$, grain sorghum RTx430 with the stalk pathogens Fusarium thapsinum (top row of panels), Macrophomina phaseolina (middle row of panels), or broth control (bottom row of panels). Mean lesion lengths are illustrated; time points with differing letters are significantly different at $P \leq 0.05$. A, Colman plants $(n=4)$ were harvested at $0,1,3,7,14$, and 18 days after inoculation and lesion lengths were determined. At day 1 , no visible lesions were observed; therefore, lesion length was considered diameter of wound ( $2 \mathrm{~mm})$; similarly at day 0 , lesion was assumed to also be diameter of wound. Standard errors $(\mathrm{SE})=12.4$ for $F$. thapsinum, 10.2 for $M$. phaseolina, and 5.9 (days $0,1,7$, and 14) or 6.8 (days 3 and 18) for broth control. B, Colman (blue) and RTx430 (red) plants ( $n=4$ each) were harvested at $0,3,6,9,13$, and 16 days after inoculation and mean lesion lengths were determined. At day 0 , lesions were assumed to be diameter of wound $(2 \mathrm{~mm})$. SE were 12.4 for both lines and all treatments. 
be susceptible to the two pathogens, even when the relatively large wound response was taken into consideration (Table 4; Fig. 1). This inconsistency may be due to differences in controlled conditions in the greenhouse versus conditions present in the field, as well as differences in inoculum and delivery (syringe injection of conidia in the field studies versus wound inoculation with mycelia in the present study) and location of inoculation (older tissue at the base of the stalk in previous field studies versus peduncle in the present study) (Tesso et al. 2005, 2010).

Lesion development within susceptible sweet sorghum Colman gave hints to aspects of colonization that could be restricted in the more resistant lines. For example, initial infection could be delayed or expansion of the lesion could be limited (Dita Rodriguez et al. 2006; Dugan et al. 2011; Onfroy et al. 2007). The approximate timing of lesion initiation ( 2 to 3 days) and lesion expansion (9 to 13 days) were determined within Colman peduncles inoculated by either F. thapsinum or M. phaseolina. "Lesions" were defined as pigmentation along the length of the peduncle in this study, which is a plant response to wounding and infection (Funnell and Pedersen 2006b; Funnell-Harris et al. 2013). Response to wounding or to fungal infection was not yet visible by day 1 but was clearly visible by day 3 following inoculation. Timing of this response is consistent with previous observations where seedling epicotyls were inoculated with $F$. thapsinum, $F$. proliferatum, or the nonpathogenic Bipolaris maydis (Y. Nisik. \& C. Miyake) Shoemaker (Huang and Backhouse 2005; Lo and Nicholson 1998). Because the peduncle inoculation assay was destructive, it prevented assessment of lesion development of an individual plant over the time course. Nonetheless, combined analyses of variances of slopes and mean lesion lengths at individual time points allowed conclusions to be drawn as to initiation and expansion of lesions within Colman peduncles. Lesion expansion in another susceptible line, RTx430, began sooner and expanded rapidly 13 to 16 days after $F$. thapsinum inoculation. Further investigations will be needed to establish the timing of lesion development within RTx430 peduncles. Defining the stages of lesion development within the susceptible Colman peduncles will facilitate the discovery of molecular and biochemical responses to stalk pathogens during lesion development in susceptible and resistant sweet sorghum lines.

\section{Acknowledgments}

We thank J. Toy for production of greenhouse-grown grain, T. Gries and S. Finegan for maintenance of plants and assistance with inoculations, and K. Steinhauer and M. Sederberg for laboratory and greenhouse assistance. This work was supported by United States Department of Agriculture-Agricultural Research Service CRIS project number 5440-21220-032-00D.

\section{Literature Cited}

Audilakshmi, S., Mall, A. K., Sivarnalatha, M., and Seetharama, N. 2010. Inheritance of sugar concentration in stalk (brix), sucrose content, stalk and juice yield in sorghum. Biomass Bioenergy 34:813-820

Bean B.W., Baumhardt R.L., McCollum, F.T., III, and McCuistion, K. C. 2013. Comparison of sorghum classes for grain and forage yield and forage nutritive value. Field Crops Res. 142:20-26.

Boedo, C., Benichou, S., Berruyer, R., Bersihand, S., Dongo, A., Simoneau, P., Lecomte, M., Briard, M., Le Clerc, V., and Poupard, P. 2012. Evaluating aggressiveness and host range of Alternaria dauci in a controlled environment. Plant Pathol. 61:63-75.

Borrell, A. K., Mullet, J. E., George-Jaeggli, B., van Costerom, E. J., Hammer, G. L., Klein, P. E., and Jordan, D. R. 2014. Drought adaptation of stay-green sorghum is associated with canopy development, leaf anatomy, root growth, and water uptake. J. Exp. Bot. 65:6251-6263.

Bramel-Cox, P. J., and Claflin, L. E. 1989. Selection for resistance to Macrophomina phaseolina and Fusarium moniliforme in sorghum. Crop Sci. 29:1468-1472.

Buttner, G., Pfahler, B., and Manlander, B. 2004. Greenhouse and field techniques for testing sugar beet for resistance to Rhizoctonia root and crown rot. Plant Breed. 123:158-166.

Carpita N. C., and McCann, M. C. 2008. Maize and sorghum: Genetic resources for bioenergy grasses. Trends Plant Sci. 13:415-420.

Davila-Gomez, F. J., Chuck-Hernandez, C., Perez-Carrillo, E., Rooney, W. L., and Serna-Saldivar, S. O. 2011. Evaluation of bioethanol production from five different varieties of sweet and forage sorghums (Sorghum bicolor (1.). Moench). Ind. Crops Prod. 33:611-616.

Dita Rodriguez, M. A., Bommonschenkel, S. H., Matsuoka, K., and Mizubuti, E. S. G. 2006. Components of resistance to early blight in four potato cultivars: Effect of leaf position. J. Phytopathol. 154:230-235.
Dogget, H. 1988. Sorghum, second ed. Longman Group UK Limited, Essex, Great Britain.

Dorrance, A. E., and Inglis, D. A. 1997. Assessment of greenhouse and laboratory screening methods for evaluating potato foliage for resistance to late blight Plant Dis. 81:1206-1213.

Dugan, F. M., Hellier, B. C., and Lupien, S. L. 2011. Resistance to Penicillium alli in accessions from a National Plant Germplasm system Allium collection. Crop Prot. 30:483-488

Eggleston, G., Cole, M., and Audrzejewski, B. 2013. New commercially viable processing technologies for the production of sugar feedstocks from sweet sorghum (Sorghum bicolor L. Moench) for manufacture of biofuels and bioproducts. Sugar Tech. 15:232-249.

English, J. T., and Beuselinck, P. R. 2000. Methods for evaluating birdsfoot trefoil and shoot blight caused by Rhizoctonia spp. Crop Sci. 40:841-843.

Funnell, D. L., and Pedersen, J. F. 2006a. Reaction of sorghum lines genetically modified for reduced lignin content to infection by Fusarium and Alternaria spp. Plant Dis. 90:331-338.

Funnell, D. L., and Pedersen, J. F. 2006b. Association of plant color and pericarp color with colonization of grain by members of Fusarium and Alternaria in near-isogenic sorghum lines. Plant Dis. 90:411-418.

Funnell-Harris, D. L., and Pedersen, J. F. 2008. Inoculation strategies to assess biological interactions between Fusarium and Alternaria species infecting sorghum. Can. J. Plant Pathol. 30:404-413.

Funnell-Harris, D. L., Pedersen, J. F., and Sattler, S. E. 2010. Alteration in lignin biosynthesis restricts growth of Fusarium spp. in brown midrib sorghum. Phytopathology 100:671-681.

Funnell-Harris, D. L., Prom, L. K., Sattler, S. E., and Pedersen, J. F. 2013 Response of near-isogenic sorghum lines, differing at the $P$ locus for plant color, to grain mould and head smut fungi. Ann. Appl. Biol. 163:91-101.

Funnell-Harris, D. L., Sattler, S. E., and Pedersen, J. F. 2014. Response of Fusarium thapsinum to sorghum brown midrib lines and to phenolic metabolites. Plant Dis. 98:1300-1308.

Huang, L.-D., and Backhouse, D. 2005. Induction of defence responses in roots and mesocotyls of sorghum seedlings by inoculation with Fusarium thapsinum and F. proliferatum, wounding and light. J. Phytopathol. 153:522-529.

Jardine, D. J., and Leslie, J. F. 1992. Aggressiveness of Gibberella fujikuroi (Fusarium moniliforme) isolates to grain sorghum under greenhouse conditions. Plant Dis. 76:897-900.

Keeney, D. R., and DeLuca, T. H. 1992. Biomass as an energy source for the Midwestern U.S. Am. J. Alt. Agric. 7:137-144.

Lo, S.-C. C., and Nicholson, R. L. 1998. Reduction of light-induced anthocyanin accumulation in inoculated sorghum mesocotyls. Plant Physiol. 116:979-989.

Luo, S., Xu, T., Chen, L., Chen, J., Rao, C., Xiao, X., Wan, Y., Zeng, G., Long, F., Liu, C., and Liu, Y. 2012. Endophyte-assisted promotion of biomass production and metal-uptake of energy crop sweet sorghum by plantgrowth-promoting endophyte Bacillus sp. SLS18. Appl. Microbiol. Biotechnol. 93:1745-1753.

Lv, P., Ji, G., Han, Y., Hou, S., Li, S., Ma, X., Du, R., and Liu, G. 2013 Association analysis of sugar yield-related traits in sorghum [Sorghum bicolor (L.)]. Euphytica 193:419-431.

Major, D. J., Rood, S. B., and Miller, F. R. 1990. Temperature and photoperiod effects mediated by the sorghum maturity genes. Crop Sci. 30:305-310.

Miron, J., Zuckerman, E., Sadeh, D., Adin, G., Nikbachat, M., Yosef, E., BenGhedalia, D., Carmi, A., Kipnis, T., and Soloman, R. 2005. Yield, composition and in vitro digestibility of new forage sorghum varieties and their ensilage characteristics. Anim. Feed Sci. Technol. 120:17-32.

Nimir, N. E. A., Lu, S., Zhou, G., Guo, W., Ma, B., and Wang, Y. 2015 Comparative effects of gibberellic acid, kinetin and salicylic acid on emergence, seedling growth and the antioxidant defence system of sweet sorghum (Sorghum bicolor) under salinity and temperature stresses. Crop Pasture Sci. 66 145-157.

Odvody, G. N., and Dunkle, L. D. 1979. Charcoal stalk rot of sorghum: Effect of environment on host-parasite relations. Phytopathology 69:250-254.

Onfroy, C., Baranger, A., and Tivoli, B. 2007. Biotic factors affecting the expression of partial resistance in pea to ascochyta blight in a detached stipule assay. Eur. J. Plant Pathol. 119:13-27.

Padley, J. L. D., Kabelka, E. A., Roberts, P. D., and French, R. 2008. Evaluation of Cucurbita pepo accessions for crown rot resistance to isolates of Phytophthora capsici. HortScience 43:1996-1999.

Paul, P. A., and Munkvold, G. P. 2005. Influence of temperature and relative humidity on sporulation of Cercospora zeae-maydis and expansion of gray leaf spot lesions on maize leaves. Plant Dis. 89:624-630.

Pedersen, E. A., and Morrall, R. A. A. 1994. Effects of cultivar, leaf wetness duration, temperature, and growth stage on infection and development of Ascochyta blight of lentil. Phytopathology 84:1024-1030.

Pfeiffer, T. W., Bitzer, M. J., Toy, J. J., and Pedersen, J. F. 2010. Heterosis in sweet sorghum and selection of a new sweet sorghum hybrid for use in syrup production in Appalachia. Crop Sci. 50:1788-1794.

Prasad, P. V. V., Pisipati, S. R., Mutava, R. N., and Tuinstra, M. R. 2008 Sensitivity of grain sorghum to high temperature stress during reproductive development. Crop Sci. 48:1911-1917.

Rajewski, J. F., and Francis, C. A. 1991. Defoliation effects on grain fill, stalk rot, and lodging of grain sorghum. Crop Sci. 31:353-359. 
Rao, K. N., Reddy, V. S., Williams, R. J., and House, L. R. 1980. The ICRISAT charcoal rot resistance program. Pages 315-321 in: Proc. Int. Workshop Sorghum Dis. R. A. F. R.J. Williams, and L. K. Mughogho, eds. International Crops Research Institute for the Semi-Arid Tropics, Hyderabad, India.

Reed, J. E., and Partridge, J. E. 1983. Fungal colonization of stalks and roots of grain sorghum during the growing season. Plant Dis. 67:417-420.

Russin, J. S., Carter, C. H., and Griffin, J. L. 1995. Effects of grain sorghum (Sorghum bicolor) herbicides on charcoal rot fungus. Weed Technol. 9: 343-351.

Saleh, A. A., Ahmed, H. U., Todd, T. C., Travers, S. E., Zeller, K. A., Leslie, J. F., and Garrett, K. A. 2010. Relatedness of Macrophomina phaseolina isolates from tallgrass prairie, maize, soybean and sorghum. Mol. Ecol. 19:79-91.

SAS. 2002-2008. SAS/STAT software, version 9.2 of the SAS System for Windows. SAS Institute Inc., Cary, NC.

Shiringani, A. L., Frisch, M., and Friedt, W. 2010. Genetic mapping of QTLs for sugar-related traits in a RIL population of Sorghum bicolor L. Moench. Theor. Appl. Genet. 121:323-336.

Shpialter, L., David, D. R., Dori, I., Yermiahu, U., Pivonia, S., Levite, R., and Elad, Y. 2009. Cultural methods and environmental conditions affecting gray mold and its management in lisianthus. Phytopathology 99:557-570.

Smith, C. W., and Frederiksen, R. A., eds. 2000. Sorghum: Origin, History, Technology and Production, John Wiley and Sons, Inc., New York.

Smith, G. A., Bagby, M. O., Lewellan, R. T., Doney, D. L., Moore, P. H., Hills, F. J., Campbell, L. G., Hogaboam, G. J., Coe, G. E., and Freeman, K. 1987. Evaluation of sweet sorghum for fermentable sugar production potential. Crop Sci. 27:788-793.

Su, G., Suh, S.-O., Schneider, R. W., and Russin, J. S. 2001. Host specialization in the charcoal rot fungus, Macrophomina phaseolina. Phytopathology 91: 120-126.

Teetor V. H., Duclos D. V., Wittenberg E. T., Young K. M., Chawhuaymak J., Riley, M. R., and Ray, D. T. 2011. Effects of planting date on sugar and ethanol yield of sweet sorghum grown in Arizona. Ind. Crops Prod. 34: 1293-1300.

Tenkouano, A., Miller, R. R., Frederiksen, R. A., and Rosenow, D. T. 1993. Genetics of nonsenescence and charcoal rot resistance in sorghum. Theor. Appl. Genet. 85:644-648.
Tesso, T., and Ejeta, G. 2011. Stalk strength and reaction to infection by Macrophomina phaseolina of brown midrib maize (Zea mays) and sorghum (Sorghum bicolor). Field Crops Res. 120:271-275.

Tesso, T. T., Claflin, L. E., and Tuinstra, M. R. 2005. Analysis of stalk rot resistance and genetic diversity among drought tolerant sorghum genotypes. Crop Sci. 45:645-652.

Tesso, T. T., Ochanda, N., Little, C. R., Claflin, L., and Tuinstra, M. R. 2010 Analysis of host plant resistance to multiple Fusarium species associated with stalk rot disease in sorghum [Sorghum bicolor (L.) Moench]. Field Crops Res. 118:177-182.

Upadhyaya, H. D., Pundir, R. P. S., Dwivedi, S. L., Gowda, C. L. L., Reddy, V. G., and Singh, S. 2009. Developing a mini core collection of sorghum for diversified utilization of germplasm. Crop Sci. 49:1769-1780.

Wang, M. L., Xhu, C., Barkley, N. A., Chen, Z., Erpelding, J. E., Murray, S. C. Tuinstra, M. R., Tesso, T., Pederson, G. A., and Yu, J. 2009. Genetic diversity and population structure analysis of accessions in the US historic sweet sorghum collection. Theor. Appl. Genet. 120:13-23.

Whitfield, M. B., Chinn, M. S., and Veal, M. W. 2012. Procession of materials derived from sweet sorghum for biobased products. Ind. Crops Prod. 37 362-375.

Wu, X., Jampala, B., Robbins, A., Hays, D., Yan, S., Xy, F., Rooney, W., Peterson, G., Shi, Y.-C., and Wang, D. 2010. Ethanol fermentation performance of grain sorghums (Sorghum bicolor) with modified endosperm matrices. J. Agric. Food Chem. 58:9556-9562.

Yanase, M., Tarumoto, I., and Kasuga, S. 2008. Effects of day-length and night temperature on the flowering of sorghum varieties with a dominant thermosensitivity gene. Grassl. Sci. 54:57-61.

Zegada-Lizarazu, W., and Monti, A. 2012. Are we ready to cultivate sweet sorghum as a bioenergy feedstock? A review on field management practices. Biomass Bioenergy 40:1-12.

Zummo, N. 1971. Foliage diseases of sweet sorghum. Grain Sorghum Res. Util. Conf. Bienn. Program Proc. 7:80-83.

Zummo, N. 1986. Red spot (Helminthosporium rostratum) of sweet sorghum and sugarcane, a new disease resembling anthracnose and red rot. Plant Dis. 70:800.

Zummo, N., and Broadhead, D. M. 1984. Sources of resistance to rough leaf spot disease in sweet sorghum. Plant Dis. 68:1048-1049. 